\title{
Comparative Assessment of the Trophic Level of the Sevastopol and Yuzhnaya Bays Using E-TRIX Index
}

\author{
K. A. Slepchuk*, T. V. Khmara, E. V. Man'kovskaya \\ Marine Hydrophysical Institute, Russian Academy of Sciences, Sevastopol, Russian Federation \\ *e-mail: skira@mhi-ras.ru
}

The ecological state of the Sevastopol Bay and the Yuzhnaya Bay is compared by their trophic level using the E-TRIX index. E-TRIX is defined by four state variables, which are strongly correlated with primary production: chlorophyll $a$, oxygen as absolute \% deviation from saturation, dissolved inorganic nitrogen, and total phosphorous. The annual dynamics of biogenic elements is calculated; the one-dimensional water quality model, which has been calibrated for the referred water areas, is used. The annual E-TRIX index variations in the bays are compared; the correlation coefficients between E-TRIX and its parameters are calculated; the contributions of E-TRIX variables are estimated.

The annual variation of biogeochemical parameters in the Sevastopol and Yuzhnaya bays has been simulated and E-TRIX index has been estimated. The calculations have showed that on the average the Yuzhnaya Bay has higher trophic level: the average E-TRIX index equals 4.47. In the Sevastopol Bay, the average E-TRIX value equals 4.01. The maximum values of the index have reached 5.53 for the Yuzhnaya Bay and 4.55 for the Sevastopol Bay. However, when the level of phosphates concentration which are the main limiting nutrient elements in the Sevastopol Bay is higher than in the Yuzhnaya Bay (from early July to middle August), the trophic index in the Yuzhnaya Bay is lower than in the Sevastopol Bay.

The relative contribution of components in the E-TRIX index has been estimated. It has been revealed that the main factor determining the trophic level in the Sevastopol and Yuzhnaya bays water is the concentration of dissolved inorganic nitrogen. The contributions of the other components in the E-TRIX index are equivalent.

Keywords: trophic level, E-TRIX index, water quality model, the Sevastopol Bay, the Yuzhnaya Bay.

DOI: 10.22449/1573-160X-2017-5-60-70

(c) 2017, K. A. Slepchuk*, T. V. Khmara, E. V. Man’kovskaya

(C) 2017, Physical Oceanography

\section{Introduction}

The state of semi-enclosed basins in impact zones is among the most urgent problems due to the increasing anthropogenic load. Its consequences may result in serious environmental problems including a significant decrease in the water quality in gulfs and bays [1].

One of the adverse consequences of anthropogenic impact on the ecological state of the marine environment can be an increase in the trophic level of the water area (water body). The water eutrophication is often resulted from the excessive input of nutrients and easily oxidized organic matter, the main source of which are river runoff and industrial wastewater. Their impact is of a local nature.

There is no universal method for assessing the sea water trophic level and generally accepted methods applied in practice. For defined study an approach determined by the indicators and their number in the calculation of various environmental indexes, taking into account a limited set of measured parameters and indicators of the marine environment, is chosen. 
The trophic index E-TRIX [2] is an integrated complex indicator associated with the phytoplankton primary production (the content of photosynthetic pigments, mainly chlorophyll $a$ ) and the nutrient concentration.

The advantage of E-TRIX over many other indexes with which it is also possible to assess the water quality is that the standard hydrochemical and hydrobiological monitoring data are used for calculation. This allows one to perform correctly a comparative analysis of the ecological water state in different marine water areas according to their trophic level.

In different researches the authors use E-TRIX index calculated according to monitoring observations for various shallow water areas: near-shore zone of the Adriatic and Tyrrhenian seas [3, 4], certain gulfs of the Marmara Sea [5], the northeastern shelf of the Black Sea [6], the Danube region, Bulgarian near-shore zone, the Odessa Gulf in the north-western Black Sea [7, 8], Sevastopol near-shore zone [9, 10].

In [9], E-TRIX index was simulated on the basis of monthly hydrochemical monitoring data as well as the data on the chlorophyll $a$ concentration from February 2002 to November 2003 near the mussel farm located at the exit from the Sevastopol Bay.

However, field observations were not always carried out in sufficient amount at different points of space. Numerical modeling not only allows to fill gaps in the points where the field data is absent but also to perform a model assessment of the ecosystem state under conditions of its components variability. In addition, numerical modeling provides the ecosystem evolution forecast under the mutual effect of natural-climatic and anthropogenic factors.

In [4], E-TRIX index calculated from the multi-year monitoring data for the Adriatic Sea was compared with the corresponding index obtained from the biogeochemical model, and their comparability is shown.

The main purpose of the present work is to carry out a comparative analysis of water state of the Sevastopol and Yuzhnaya bays by E-TRIX trophic index with biogeochemical parameters calculated from the water quality model. It should be pointed out that simulation of biochemical processes are carried out for the Sevastopol Bay (which also includes the Yuzhnaya Bay).

The Sevastopol Bay is a semi-enclosed water area oriented in a latitudinal direction from the east to west with a difficult water exchange with an open (less polluted) part of the sea. The bay is characterized by shallow water and intensive anthropogenic load which is also related to the Chernaya River runoff (Fig. 1).

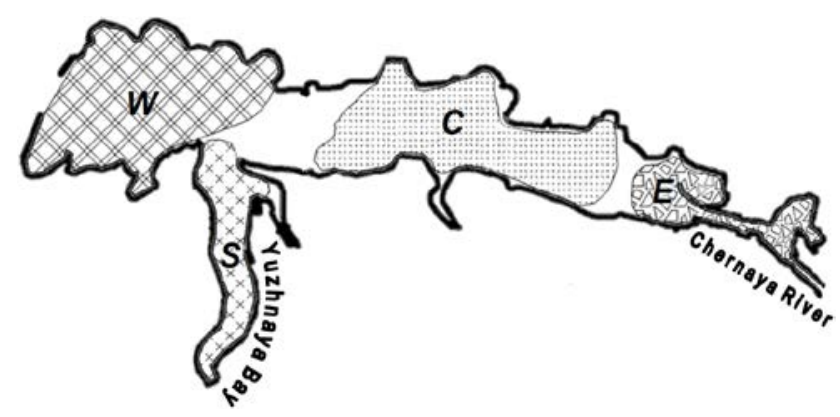

Fig. 1. The Sevastopol Bay zoning by to water pollution level (according to [11]): the areas of weak $(W)$, moderate $(E)$, strong $(C)$ and very strong $(S)$ pollution 
As a water area of active economic use, the bay actually serves as a reservoir into which get industrial and domestic wastewater as well as stormwater from the catchment area. Every day up to 10-15 thousand $\mathrm{m}^{3}$ of untreated or conditionallytreated wastewaters are discharged into the bay. With these wastewaters a wide range of pollutants get into the water (in the concentrations which significantly exceed the permissible standards [11]).

Depending on the localization of pollution sources, morphometry and hydrometeorological conditions, in the Sevastopol Bay both relatively "clean" zones and the ones of consistently high pollution (for example, the Yuzhnaya Bay) are formed.

In [11] the Sevastopol Bay was divided into four zones. Geographically, the western region $(W)$ is a weak pollution zone, the eastern $(E)$ - is a moderate one. The central part of the bay $(C)$ belongs to the strong pollution zone. In comparison with the other parts of the bay, the Yuzhnaya Bay $(S)$ is characterized by very strong pollution. This division is rather relative.

Due to limited water exchange with the main water area and to the use as a location of numerous ship berths, the Yuzhnaya Bay ranks first among other Sevastopol bays in terms of industrial, domestic and storm sewage. Its apex is characterized by freshened areas and the intensity of water freshening is unstable during a year.

The Sevastopol Bay pollution level (in accordance with the zoning given above) based on the processing of Oceanographic Database of the Marine Hydrophysical Institute for 1998-2011 for the surface water is represented as diagrams (Fig. 2).
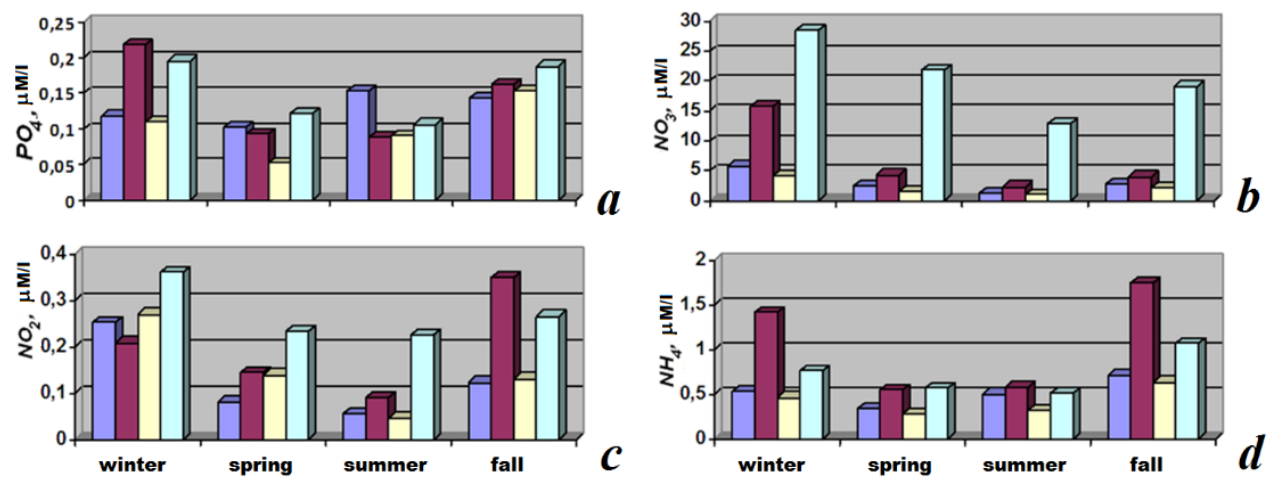

$\square W \square E \square C \square S$

Fig. 2. Seasonal change of phosphate (a), nitrate $(b)$, nitrite $(c)$ and ammonium $(d)(\mu \mathrm{M} / \mathrm{l})$ content in the waters of certain areas of the Sevastopol Bay chosen by the pollution level according to [11]

The Yuzhnaya Bay is the most polluted water area regardless of the season. This is particularly represented in the concentration of nitrates and nitrites as well as, to a lesser extent, in the one of ammonium. The absence of a pronounced seasonal dependence indicates the predominant anthropogenic nature of the nutrients getting into the bay. 
The Yuzhnaya Bay surface waters (especially at its edge part) are characterized by the maximum concentrations of nitrogen compounds. More than 20 -fold excess of nitrate concentration over the average values obtained for the Sevastopol Bay (Fig. 2) is observed at that [12].

\section{Research materials and methods}

For assessing the water trophic level, E-TRIX index which is a function of dissolved oxygen content and total phosphorus concentration, mineral forms of nitrogen and chlorophyll $a$ [2] is used. The last indicator characterizes the primary production of phytoplankton.

According to [2], trophic index is determined as following:

$$
E-T R I X=(\lg [C h D \% O N \cdot P]+1.5) / 1.2,
$$

where $C h$ is a chlorophyll $a$ concentration, $\mu \mathrm{g} / \mathrm{dm}^{3} ; D \% O$ is a deviation of the dissolved oxygen content in absolute values from $100 \%$ saturation; $N$ is a concentration of dissolved mineral nitrogen, $\mu \mathrm{g} / \mathrm{dm}^{3} ; P$ is total phosphorus concentration, $\mu \mathrm{g} / \mathrm{dm}^{3}$.

$E$-TRIX index vary from 0 to 10 [2]. Depending on E-TRIX, four trophic levels are determined: low (<4); medium (4-5); high (5-6) and very high (6-10).

At $E-T R I X>6$ the sea regions under study are characterized by a high content of nutrients, low transparency and the possibility of hypoxia occurrence in the bottom layer. Conversely, at $E-T R I X<4$ the concentration of the main nutrients is insignificant; the waters are well aerated throughout the water column and are high transparent [13].

The concentration of chlorophyll $a$, dissolved oxygen, mineral nitrogen and total phosphorus required for E-TRIX index simulation were calculated from the one-dimensional water quality model and its block of eutrophication [14].

For the Sevastopol Bay, the model was calibrated and proved itself well in calculating the hydrochemical parameters of the bay as a whole and its separated parts $[15,16]$.

Meteorological data (wind velocity and direction, air temperature, photosynthetically active radiation, humidity and the amount of clouds) and the data on annual discharge and runoff of dissolved substances of rivers flowing into the water area were used as an input data. Annual variations of transparency, sea water temperature, salinity, concentrations of phytoplankton, nutrients, oxygen, organic phosphorus and nitrogen which are set for January $1^{\text {st }}$ of the design year were also used.

\section{Research results and their analysis}

To assess the water trophic level in the Sevastopol Bay (including the Yuzhnaya Bay) and the Yuzhnaya Bay separately, the annual variation of chemical-biological water parameters applied in the E-TRIX index simulation was calculated.

E-TRIX index annual variation for the Yuzhnaya and the Sevastopol Bays is shown in Fig. 3. During the year E-TRIX varied from 3.30 to 5.53 for the Yuzhnaya Bay and from 3.59 to 4.55 for the Sevastopol Bay. On average, the Yuzhnaya Bay trophic value $\left(E-T R I X_{\text {mean }}=4.47\right)$ is higher than the one for the Sevastopol Bay 
$\left(E-T R I X_{\text {mean }}=4.01\right)$. The exception is the period from the beginning of July to the middle of August (210 $-255^{\text {th }}$ computed days) in which the Yuzhnaya Bay trophic index is lower than the one of the Sevastopol Bay. This can be explained by the fact that in the given period phosphate concentration in the Yuzhnaya Bay was lower than in the Sevastopol Bay (Fig. 2) which decreased the amount of nutritional substances and resulted in the decrease of phytoplankton biomass and trophic index down to 3.30 .

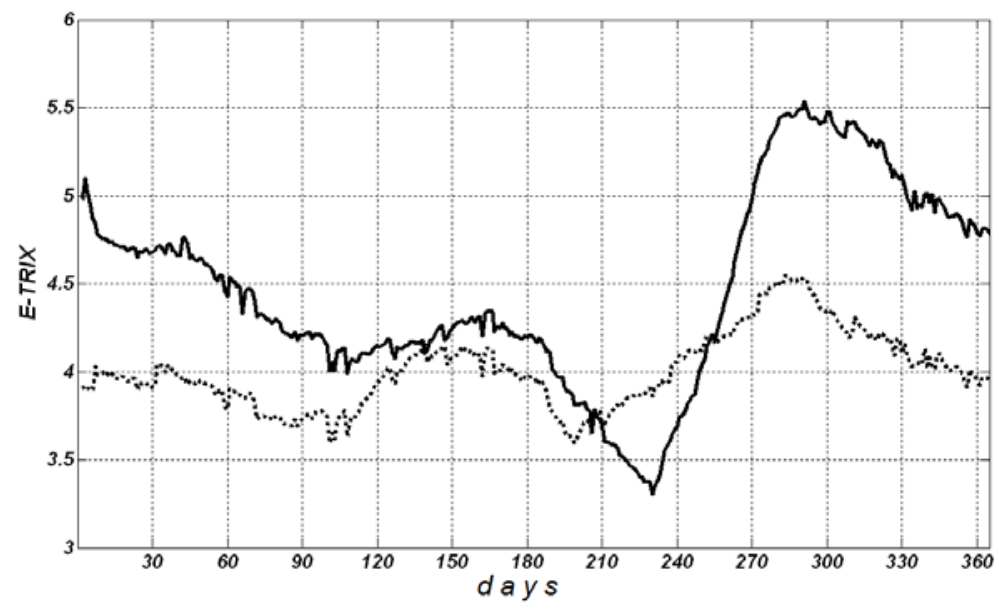

Fig. 3. E-TRIX index annual variation of the Yuzhnaya Bay (-) and the Sevastopol Bay (- - -)

For the Sevastopol Bay the minimum index (3.59) falls on the second part of July $\left(190-200^{\text {th }}\right.$ day), the maximum one - on the middle of October $\left(280-290^{\text {th }}\right.$ days). For the Yuzhnaya Bay the minimum index falls on (3.30) falls on July (230 ${ }^{\text {th }}$ day), the maximum one (5.53) - on early October ( $270^{\text {th }}$ day). In both cases the maximum index coincides with the autumn peak of the phytoplankton bloom. The second local maximum falls on the spring phytoplankton bloom.

Thus, the Sevastopol Bay water trophic level can be characterized as transitional from low to high one. From April to May (123-175 ${ }^{\text {th }}$ days) and from September to November (238-353 ${ }^{\text {th }}$ days) there is a moderate trophic level $(4<E-T R I X<5)$. In other days of a computed year trophic level is low ( $4>E-T R I X)$.

The Yuzhnaya Bay waters mainly belong to the moderate trophic level $(4<E-T R I X<5)$. However, from the middle of July to the middle of September $\left(191-249^{\text {th }}\right.$ days) the Yuzhnaya Bay trophic level is low $(4>E-T R I X)$ and from October to November $\left(272-300^{\text {th }}\right.$ days) it is high $(5<E-T R I X<6)$.

In Fig. 4 and 5 the annual variation of E-TRIX index combined with the parameters (concentration of chlorophyll $a$, total phosphorus, mineral nitrogen and saturation of water with oxygen) in the Sevastopol and the Yuzhnaya Bays, respectively, is given.

On the basis of the simulated data for the Sevastopol and the Yuzhnaya Bays correlation coefficients between the E-TRIX index and the concentration of mineral nitrogen, total phosphorus and chlorophyll $a$ were calculated. 

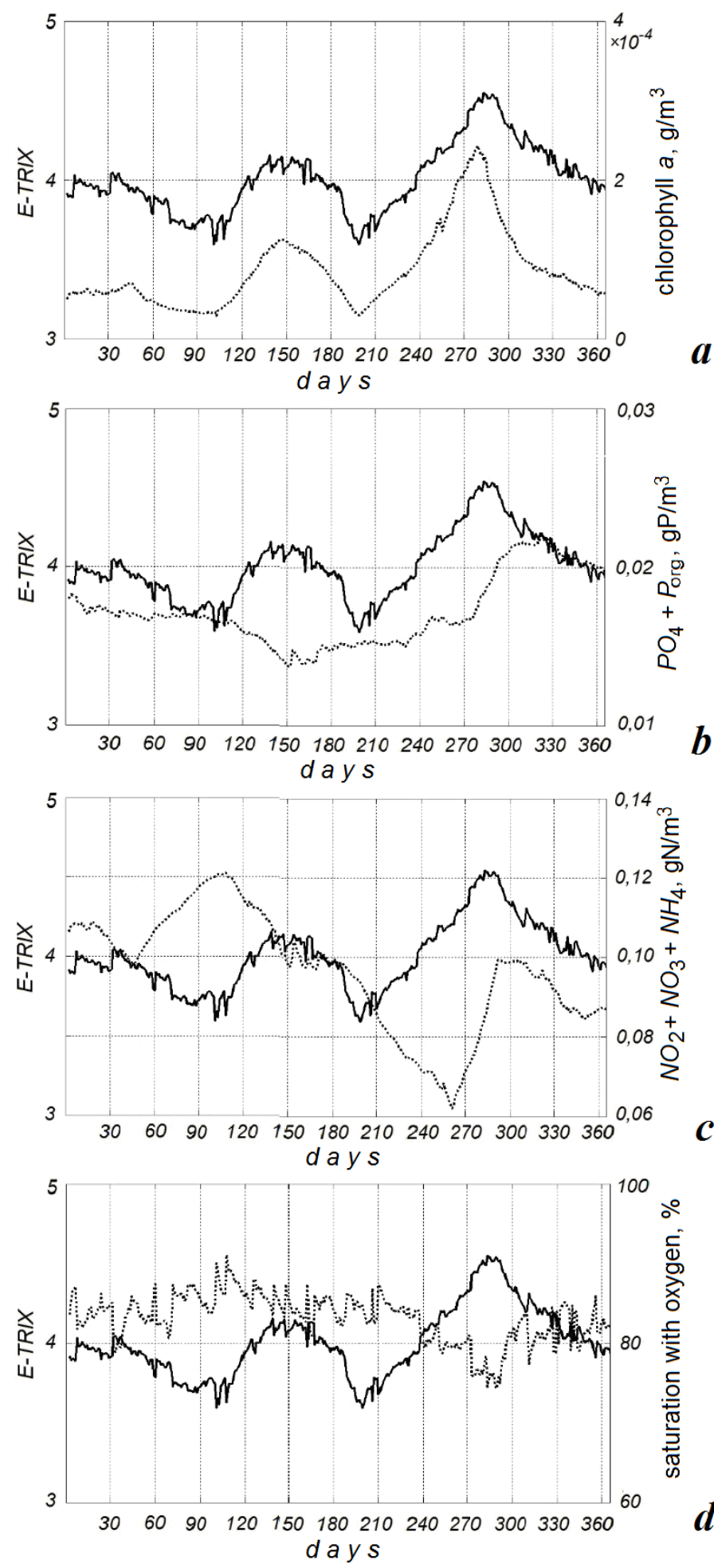

Fig. 4. Annual variation of E-TRIX index (-) and the concentrations (- - -) of chlorophyll $a(a)$, total phosphorus $(b)$, mineral nitrogen $(c)$ and water saturation with the oxygen $(d)$ in the Sevastopol Bay 

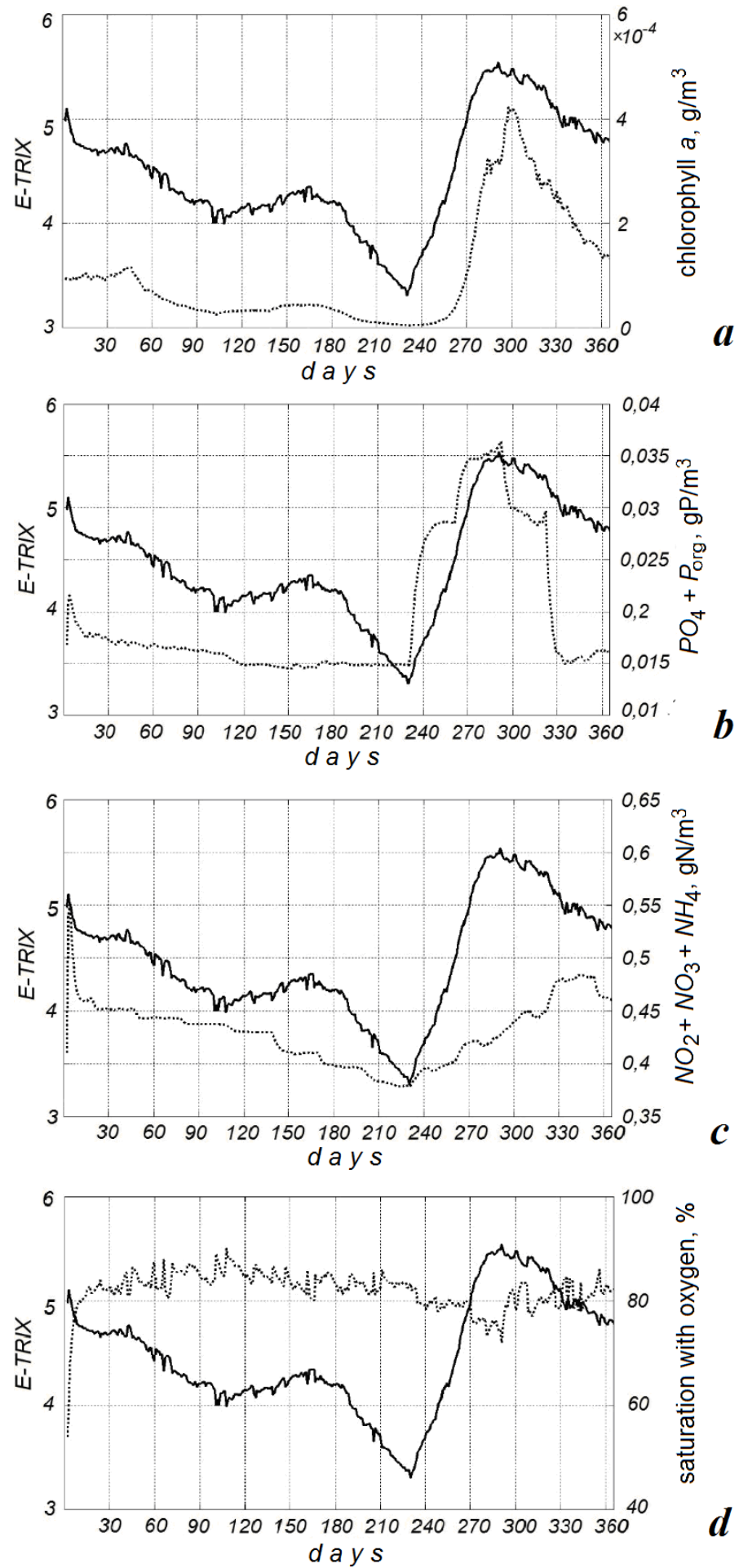

Fig. 5. Annual variation of E-TRIX index (-) and the concentrations (- - -) of chlorophyll $a(a)$, total phosphorus $(b)$, mineral nitrogen $(c)$ and water saturation with the oxygen $(d)$ in the Yuzhnaya Bay waters 
For the Sevastopol Bay the highest values were obtained for E-TRIX correlation coefficient with a chlorophyll $a$ concentration $(r=0.89)$ and deviation in absolute values of the dissolved oxygen content from $100 \%$ saturation $(r=-0.78)$ which indicates rather good relation of E-TRIX index values with the given parameters. The correlation with the concentrations of mineral nitrogen $(r=-0.42)$ and total phosphorus $(r=0.41)$ is weak.

For the Yuzhnaya Bay the highest E-TRIX correlation coefficients were obtained with the concentrations of chlorophyll $a(r=0.89)$ and mineral nitrogen $(r=0.66)$. The correlation with total phosphorus concentration $(r=0.57)$ is weak, the one with the dissolved oxygen content deviation in absolute values from $100 \%$ saturation $(r=-0.48)$ is weak.

Negative feedback of $E$-TRIX with certain parameters $(D \% O, N)$ can be clearly seen in the annual variation of these values (Fig. 4 and 5).

Simulation of the relative contribution of components included into the E-TRIX index is represented in Tables 1 and 2. E-TRIX is calculated by successive elimination of one or another parameter (replacing it by one) included into the computational equation. Ch chlorophyll contribution was negative because simulated values of this parameter are less than one and its replacement by one leads to the increase of actual E-TRIX. Other parameters included in E-TRIX have the values which are more than one and exclusion of any of them leads to a decrease in the actual value of $E$-TRIX.

Table 1

\section{Relative contributions (\%) of $E$-TRIX components for the Sevastopol and the Yuzhnaya Bays}

\begin{tabular}{|c|c|c|c|c|}
\hline \multirow{2}{*}{$\begin{array}{c}E-T R I X \\
\text { components }\end{array}$} & \multicolumn{2}{|c|}{ the Sevastopol Bay } & \multicolumn{2}{|c|}{ the Yuzhnaya Bay } \\
\hline & $\begin{array}{c}\text { Range of } \\
\text { values }\end{array}$ & Mean value & $\begin{array}{c}\text { Range of } \\
\text { values }\end{array}$ & Mean values \\
\hline Ch & $-35 \ldots-11$ & -24 & $-63 \ldots-6$ & -26 \\
\hline $\mathrm{D} \% \mathrm{O}$ & $22 \ldots .28$ & -25 & $19 \ldots 31$ & -24 \\
\hline$N$ & $35 \ldots 48$ & -41 & $40 \ldots 65$ & -50 \\
\hline$P$ & $23 . . .28$ & -26 & $19 . .32$ & -24 \\
\hline
\end{tabular}

Table 2

Relative contributions (\%) of E-TRIX components for the extreme indexes of the Sevastopol and the Yuzhnaya Bays

\begin{tabular}{c|ccccc}
\hline \multirow{2}{*}{ E-TRIX components } & \multicolumn{2}{|c|}{ the Sevastopol Bay } & \multicolumn{2}{c}{ the Yuzhnaya Bay } \\
\cline { 2 - 5 } & $E-T R I X_{\min }$ & $E-T R I X_{\max }$ & $E-T R I X_{\min }$ & $E-T R I X_{\max }$ \\
\hline$C h$ & -34 & -12 & -62 & -8 \\
$D \% O$ & -24 & -26 & -31 & 21 \\
$N$ & -47 & -35 & -64 & 40 \\
$P$ & -28 & -23 & -29 & 24 \\
\hline
\end{tabular}


It should be pointed out that at the maximum E-TRIX (4.55) relative contributions $N$ (35\%), $P(23 \%)$ and $C h$ contribution modulus (12\%) were minimal for the Sevastopol Bay. In its turn, at the maximum of $N(47 \%), P(28 \%)$ contributions and Ch contribution modulus (34\%) E-TRIX value is minimal (3.59). The same situations are observed for the Yuzhnaya Bay: at E-TRIX (5.53) maximum value relative contributions of $N(40 \%)$ and $C h$ modulus (8\%) were minimal and vice versa, at the maximum values of $N(64 \%), D \% O(31 \%)$ contributions and $C h$ modulus (62 \%) E-TRIX is minimal (3.30).

Thus, the concentration of nitrogen mineral forms is the main factor determining the trophic level of the Sevastopol Bay and the Yuzhnaya Bay waters. The contributions of other components included into E-TRIX are equal.

\section{Conclusion}

Modeling of annual variation of the Sevastopol Bay and the Yuzhnaya Bay biogeochemical parameter and further calculation of E-TRIX index showed that, on the average, the Yuzhnaya Bay has the higher eutrophication level: $E$-TRIX $X_{\text {mean }}=4.47$. In the Sevastopol Bay average E-TRIX is 4.01. The maximum index was 5.53 for the Yuzhnaya and 4.55 for the Sevastopol Bays. Trophic level of the Sevastopol Bay waters can be characterized as a transitional from low to medium, and the one of the Yuzhnaya Bay - basically as a medium level.

Separately stands out a situation when the Yuzhnaya Bay trophic index becomes lower than the one of the Sevastopol Bay: from early July to the middle of August (210-255 $5^{\text {th }}$ computed days of the year). This can be observed when the concentration of phosphates, the main limiting nutrients, in the Sevastopol Bay is higher than in the Yuzhnaya Bay.

When assessing the relationship between the E-TRIX index and its parameters, it was found that the highest correlation is observed with the chlorophyll $a$ concentration $(r=0.89)$ and the dissolved oxygen content deviation in absolute values from $100 \%$ saturation $(r=-0.78)$ for the Sevastopol Bay waters. For the Yuzhnaya Bay waters the highest E-TRIX correlation is observed with the concentrations of chlorophyll $a(r=0.89)$ and mineral nitrogen $(r=0.66)$.

The calculations of relative contributions of components included into E-TRIX revealed that the main factor determining eutrophication levels of the Sevastopol and the Yuzhnaya Bays is a concentration of nitrogen mineral forms. The contri-buteons of other components included into the computational E-TRIX formula are equal.

Acknowledgements. The study was carried out in Federal State Budget Scientific Institution "Marine Hydrophysical Institute of RAS" within the framework of the State Order No. 0827-2014-0010.

\section{REFERENCES}

1. $\quad$ Lillebø, A.I., Stålnacke, P. and Gooch, G.D. eds., 2015. Coastal Lagoons in Europe: Integrated Water Resource Strategies. London: IWA Publishing, 256 p. doi:10.2166/9781780406299

2. Vollenweider, R.A., Giovanardi, F., Montanari, G. and Rinaldi, A., 1998. Characterization of the Trophic Conditions of Marine Coastal Waters with Special Reference to the NW Adriatic Sea: Proposal for a Trophic Scale, Turbidity and Generalized Water Quality Index. Environmetrics, [e-journal] 9(3), pp. 329-357. doi:10.1002/(SICI)1099-095X(199805/06)9:3<329::AIDENV308>3.0.CO;2-9 
3. Giovanardi, F. and Vollenweider, R.A., 2004. Trophic Conditions of Marine Coastal Waters: Experience in Applying the Trophic Index TRIX to Two Areas of the Adriatic and Tyrrhenian Seas. Journal of Limnology, [e-journal] 63(2), pp. 199-218. doi:10.4081/jlimnol.2004.199

4. Fiori, E., Zavatarelli, M., Pinardi, N., Mazziotti, C. and Ferrari, C.R., 2016. Observed and Simulated Trophic Index (TRIX) Values for the Adriatic Sea Basin. Nat. Hazards Earth Syst. Sci., [e-journal] 16(9), pp. 2043-2054. https://doi.org/10.5194/nhess-16-2043-2016

5. Balkis, N., Toklu-Aliçli, B. and Balci, M., 2012. Evaluation of Ecological Quality Status with the Trophic Index (TRIX) Values in the Coastal Waters of the Gulfs of Erdek and Bandirma in the Marmara Sea. In: Dr. Voudouris, ed. 2012. Ecological Water Quality - Water Treatment and Reuse. Rijeka: In Tech, pp. 3-22. doi:10.5772/33698

6. Romanova, N.D., Chasovnikov, V.K., Arashkevich, E.G., Mosharov, S.A., Nikishina, A.B., Kostyleva, A.V. and Louppova, N.E., 2016. Evaluation of Ecosystem Status in the ShelfSlope Zone of the Northeastern Black Sea Based on the Trophic Index (TRIX). Oceanology, [e-journal] 56(1), pp. 114-117. doi:10.1134/S000143701601015X

7. Orlova, I.G., Pavlenko, N.E., Ukrainsky, V.V. and Popov, Yu.I., 2007. Sostoyanie Evtrofirovannosti Vod Severo-Zapadnoy Chasti Chernogo Morya po Rezul'tatam Mnogoletnego Kompleksnogo Monitoringa [Euthrophication of Water in the Northwest Black Sea According to the Long-Term Complex Monitoring]. In: V.A. Ivanov, ed. 2007. Ekologicheskaya Bezopasnost' Pribrezhnoy i Shel'fovoy Zon i Kompleksnoe Ispol'zovanie Resursov Shel'fa [Ecological Safety of Coastal and Shelf Zones and Comprehensive Use of Shelf Resources]. Sevastopol: MGI NANU. Issue 15, pp. 32-43 (in Russian).

8. Tuchkovenko, Yu.S., Ivanov, V.A. and Sapko, O.Yu., 2011. Otsenka Vliyaniya Beregovykh Antropogennykh Istochnikov na Kachestvo Vod Odesskogo Rayona Severo-Zapadnoy Chasti Chernogo Morya [Assessment of the Affect of Coastal Anthropogenic Sources on Water Quality in the Odessa Area of the North-Western Black Sea]. Sevastopol: ECOSI-Gidrofizika, 169 p. (in Russian).

9. Kuftarkova, E.A., Gubanov, V.I., Kovrigina, N.P., Eremin, I.Yu. and Senicheva, M.I., 2006. Ekologicheskaya Otsenka Sovremennogo Sostoyaniya Vod v Rayone Vzaimodeystviya Sevastopol'skoy Bukhty s Prilegayushchey Chast'yu Morya [Ecological Assessment of Modern State of Waters in the Region of Interaction of the Sevastopol Bay and Part of the Sea Contiguous to it]. Morskoy Ekologicheskiy Zhurnal, 5(1), pp. 72-91 (in Russian).

10. Gubanov, V.I., Mal'chenko, Yu.A., Kuftarkova, E.A. and Kovrigina, N.P., 2004. Diagnoz Sovremennogo Sostoyaniya Vod Sevastopol'skogo Vzmor'ya (Chernoe More) po Rezul'tatam Monitoringa Gidrokhimicheskikh Kharakteristik [Diagnosis of Modern State of Coastal Water near Sevastopol (the Black Sea) according to Monitoring of Hydrochemical Parameters]. In: V.A. Ivanov, ed. 2004. Ekologicheskaya Bezopasnost' Pribrezhnoy i Shel'fovoy Zon $i$ Kompleksnoe Ispol'zovanie Resursov Shel'fa [Ecological Safety of Coastal and Shelf Zones and Comprehensive Use of Shelf Resources]. Sevastopol: MGI NANU. Iss. 10, pp. 141-148 (in Russian).

11. Ivanov, V.A., Ovsyanyy, E.I., Repetin, L.N., Romanov, A.S. and Ignat'eva, O.G., 2006. Gidrologo-Gidrokhimicheskiy Rezhim Sevastopol'skoy Bukhty i Ego Izmeneniya Pod Vozdeystviem Klimaticheskikh i Antropogennykh Faktorov [Hydrological and Hydrochemical Regime of the Sevastopol Bay and its Changing under Influence of climatic and Antropogenic Factors]. Working Paper. Sevastopol: MGI NANU, 90 p. (in Russian).

12. Sovga, E.E., Mezentseva, I.V., Khmara, T.V. and Slepchuk, K.A., 2014. O Perspektivakh i Vozmozhnostyakh Otsenki Samoochistitel'noy Sposobnosti Akvatorii Sevastopol'skoy Bukhty [On the Prospects and Opportunity to Assess the Self-Purifying Capacity of the Sevastopol Bay]. In: V.A. Ivanov, ed. 2014. Ekologicheskaya Bezopasnost' Pribrezhnoy i Shel'fovoy Zon i Kompleksnoe Ispol'zovanie Resursov Shel'fa [Ecological Safety of Coastal and Shelf Zones and Comprehensive Use of Shelf Resources]. Sevastopol: MGI NANU. Issue 28, pp. 153-164 (in Russian). 
13. Moncheva, S. and Doncheva, V., 2000. Eutrophication Index ((E) TRIX) - an Operational Tool for the Black Sea Coastal Water Ecological Quality Assessment and Monitoring. In: International Symposium “The Black Sea Ecological Problems”. Odessa: SCSEIO, pp. 178-185.

14. Ivanov, V.A. and Tuchkovenko, Yu.S., 2006. Prikladnoe Matematicheskoe Modelirovanie Kachestva Vod Shel'fovykh Morskikh Ekosistem [Applied Mathematical Modeling of Water Quality of Shelf Marine Ecosystems]. Sevastopol: ECOSI-Gidrofizika, 368 p. (in Russian).

15. Slepchuk, K.A., 2014. Modelirovanie Godovoy Dinamiki Fitoplanktona i Biogennykh Elementov v Akvatorii Sevastopol'skoy Bukhty s Primeneniem Optimizatsionnogo Metoda Kalibrovki Biogeokhimicheskoy Modeli [Simulation of Annual Dynamics of Phytoplankton and Biogenic Elements in the Sevastopol Bay using the Optimization Method to Calibrate the Biogeochemical Model]. In: V.A. Ivanov, ed. 2014. Ekologicheskaya Bezopasnost' Pribrezhnoy i Shel'fovoy Zon i Kompleksnoe Ispol'zovanie Resursov Shel'fa [Ecological Safety of Coastal and Shelf Zones and Comprehensive Use of Shelf Resources]. Sevastopol: MGI NANU. Iss. 28, pp. 231-236 (in Russian).

16. Ivanov, V.A., Mezentceva, I.V., Sovga, E.E., Slepchuk, K.A. and Khmara, T.V., 2015. Otsenki Samoochishchayushchey Sposobnosti Ekosistemy Sevastopol'skoy Bukhty po Otnosheniyu k Neorganicheskim Formam Azota [Assessment Self-Purification Ability of the Sevastopol Bay Ecosystem in Relation to Inorganic Forms of Nitrogen]. Protsessy $v$ Geosredakh, [e-journal] 2(2), pp. 55-65. Available at: http://www.geomediacenter.ru/media/PGM_2(2)_2015.pdf [Accessed 10 April 2017] (in Russian). 